\title{
Fibrinogen Levels in Hypertensive and Normotensive: A Cross-Sectional Study from El-Obied City, Sudan
}

\author{
Ahmed Abdalla Agab Eldour1, Tarig Osman Khalafallah', Hassan Mohammed Noja1, \\ Eltayib Siddig Mohammed Saad ${ }^{2}$, Mohieldin Elsayid ${ }^{3}$, \\ Asaad Mohammed Ahmed Abd Allah Babker ${ }^{*}$ \\ ${ }^{1}$ Faculty of Medicine and Health Science, Medical Laboratory Science Program, University of Kordofan, El-Obied, \\ Sudan \\ ${ }^{2}$ Future Lab Medical Laboratories Co. Ltd., Al Kharj, KSA \\ ${ }^{3}$ Departments of Clinical Laboratory Sciences, College of Applied Medical Sciences, King Saud Bin Abdulaziz \\ University for Health Sciences, Riyadh, KSA \\ ${ }^{4}$ Department of Medical Laboratory Science, Al-Ghad International College for Health Sciences, Al-Madinah \\ Al-Monawarah, KSA \\ Email: *Azad.88@hotmail.com
}

Received 20 January 2016; accepted 26 February 2016; published 29 February 2016

Copyright (C) 2016 by authors and Scientific Research Publishing Inc.

This work is licensed under the Creative Commons Attribution International License (CC BY). http://creativecommons.org/licenses/by/4.0/

c) (i) Open Access

\section{Abstract}

Hypertension (HTN) has been defined as a blood pressure level at which an otherwise healthy person would have an increased risk of cardiovascular disease that could be mitigated through blood pressure-lowering treatment. Worldwide, hypertension is one of the most common causes of death. The prevalence of hypertension and cardiovascular disease increases with age, and has been found to be higher in those of South Asian and African ancestry, and in Aboriginal populations. Hypertension is not only one of the most important risk factors for cardiovascular disease, but also the number one modifiable risk factor for stroke. Alterations in blood coagulation system have been reported in patients of hypertension. Fibrinogen has been identified as a major independent risk factor for cardiovascular diseases. This was a descriptive cross-sectional study, conducted in Elobied teaching hospital during period from March to June 2014. The aim of this study is to determine the level of fibrinogen among hypertensive patients. Seventy percent of the patients (about 35 patients) had high fibrinogen level above $400 \mathrm{mg} / \mathrm{dl}$ compared with the control and about 30\% (15 patients) were within the normal range of $200 \mathrm{mg}-400 \mathrm{mg} / \mathrm{dl}$. This study has concluded that there was a significant increase in fibrinogen level in hypertensive patients compared to control, while the gender has no effect on the level of fibrinogen.

"Corresponding author.

How to cite this paper: Eldour, A.A.A., Khalafallah, T.O., Noja, H.M., Saad, E.S.M., Elsayid, M. and Abd Allah Babker, A.M.A. (2016) Fibrinogen Levels in Hypertensive and Normotensive: A Cross-Sectional Study from El-Obied City, Sudan. Journal of Biosciences and Medicines, 4, 28-32. http://dx.doi.org/10.4236/ibm.2016.42004 


\section{Keywords}

\section{Hypertensive, Normotensive, Fibrinogen Level, El-Obied City, Sudan}

\section{Introduction}

Hypertension (HTN) or high blood pressure is a cardiac chronic medical condition in which the arterial blood pressure is increased. Hypertension is a powerful risk factor for fatal and nonfatal cardiovascular disease events. Also it is the most common cardiovascular disease and is a major public health issue in developed as well as developing countries [1]. Randomized controlled trials have convincingly shown that treatment of hypertension reduces the risk of stroke, coronary heart disease, congestive heart failure, and mortality [1]-[3]. Patients with hypertension should be evaluated for other cardiovascular risk factors including smoking, dyslipidemia, diabetes mellitus, age older than 55 years for men and 65 years for women, body mass, physical inactivity, micro albuminuria, an estimated glomerular filtration rate and for a family history of premature cardiovascular disease (younger than 55 years in fathers or brothers and younger than 65 years in mothers or sisters) [4]. Thrombosis is one of the most complicated courses of patients with hypertension and could be developed to many of organ damages. Circulatory homoeostasis depends on the equilibrium between vasoconstricting and vasodilating forces regulating blood pressure, as well as the equilibrium between procoagulant and fibrinolytic factors regulating blood rheology [5]. Arterial disease is the major underlying factor leading to most clinically relevant cardiovascular events and these events are usually due to formation of a thrombus at the site of an atherosclerotic plaque; research has concentrated on the state of the coagulation pathways. Fibrinogen is both a coagulation factor and an acute-phase reactant that has been identified as a major independent risk factor for coronary artery [6]. There were many previous studies conducted in Sudan about the association of fibrinogen levels, D-dimer and other coagulation factors with hypertension and other heart disease. A fibrinogen level has been identified as a major independent risk factor for cardiovascular disease and measurement of fibrinogen level may be beneficial to avoid the complication of hypertension [7]-[9].

\section{Materials and Methods}

This was descriptive cross sectional study, conducted in Elobied teaching hospital during period from March to June 2014. Fifty known hypertensive patients (case) treated with anti hypertensive drugs, their age ranged (30 79 ) and divided according to their sex into (25 males and 25 females). Twenty five healthy people were assigned to the healthy control group their age ranged (30 - 79) and divided according to their sex into (13 males and 12 females). Excluding all patients with diabetes mellitus, smoking, cardiovascular diseases, liver disease and any patient under anticoagulant therapy, after consent was obtained by patients then data collected using structure questionnaire and direct interview to collect information. Then venous blood has been collected, from each subject, in 3.8\% trisodium citrate $(9: 1 \mathrm{vol} / \mathrm{vol})$. The samples were centrifuged at $2000 \mathrm{~g}$ for 15 minutes to obtain platelet-poor plasma (PPP). Plasma was separated from cells into plane container. PPP will be stored and refrigerated on (2 - 8 c) and tested within 4 hours. Fibrinogen has been measured using ready kits principle depend In the presence of excess thrombin the clotting time of the plasma is direct proportional with the level of fibrinogen in the plasma sample lie within the normal range 200 - $400 \mathrm{mg} / \mathrm{dl}$. Data analysis was performed using statistical package for social science (SPSS) software version (22). Evaluation of patient's data was performed using the t-test and Pearson correlation test. Results with $\mathrm{p}$ value $<0.05$ were considered as statistically significant.

\section{Results}

Fifty known hypertensive patients (case) treated with anti hypertensive drugs, The maximum duration of the hypertension was 10 years and the minimum duration about 5 years, their age ranged (30 - 79) and divided according to their sex in to (25 males and 25 females). Twenty five healthy people were assigned to the healthy control group their age ranged (30 - 79) and divided according to their sex in to (13 males and 12 females) (Table 1 \& Table 2). 70\% of the patients (about 35 patients) have high fibrinogen level above $400 \mathrm{mg} / \mathrm{dl} \mathrm{com-}$ pare with the control and about 30\% (15 patients) within the normal range 200 - $400 \mathrm{mg} / \mathrm{dl}$ (Table 3 \& Table 4). 


\section{A. A. A. Eldour et al.}

Table 1. Shows the distribution of study population by age.

\begin{tabular}{|c|c|c|c|c|c|c|}
\hline & \multicolumn{5}{|c|}{ Age distribution among case and control } & \multirow{2}{*}{ Total } \\
\hline & $30-39$ & $40-49$ & $50-59$ & $60-69$ & $70-79$ & \\
\hline Patient & 11 & 18 & 12 & 7 & 2 & 50 \\
\hline Control & 2 & 9 & 10 & 4 & 0 & 25 \\
\hline Total & 13 & 27 & 22 & 11 & 2 & 75 \\
\hline
\end{tabular}

Table 2. Shows the distribution study population by the gender.

\begin{tabular}{cccc}
\hline & \multicolumn{2}{c}{ Gender distribution } \\
\cline { 2 - 4 } & Male & Sex & Total \\
\hline Patient & 25 & Female & 50 \\
Control & 13 & 25 & 25 \\
Total & 38 & 12 & 75 \\
\hline
\end{tabular}

Table 3. Shows the percent of normal and high level of FIB on patients.

\begin{tabular}{ccccc}
\hline & Frequency & Percent & Valid Percent & Cumulative Percent \\
\hline Normal & 15 & 30.0 & 30.0 & 30.0 \\
High & 35 & 70.0 & 70.0 & 100.0 \\
Total & 50 & 100.0 & 100.0 \\
\hline
\end{tabular}

Table 4. Shows the comparison of FIB level between the patient and control depend up on the age.

\begin{tabular}{ccccccc}
\hline $\mathrm{p}$ & $\mathrm{N}$ & Mean & Std. Deviation & $\mathrm{t}$ & $\mathrm{df}$ & $\mathrm{p}$ value \\
\hline Patient & 50 & 432.7200 & 65.33119 & 12.691 & 73 & 0.000 \\
control & 25 & 241.8000 & 52.52380 & 13.647 & 58.382 & 0.000 \\
\hline
\end{tabular}

\section{Discussion}

Hypertension is recognized as one of the principal risk factors for cardiovascular disease. Impaired fibrinolysis may be associated with hypertension [10]. Fibrinogen is a major determinant of blood viscosity, and it is involved in haemostasis and thrombosis pathway. Elevated plasma fibrinogen is implicated in cardiovascular disease. However, it is not clear whether fibrinogen levels predict the development of hypertension. Our finding demonstrated that, the plasma fibrinogen level was significantly higher in the hypertensive patients than in control group. This result was in agreement with several studies conducted among hypertensive patients [8] [11] [12]. Also this finding is contrary to the findings reported by other workers [13] [14]. Although Sechi et al. did not observe differences in fibrinogen between hypertensive patients and normotensive controls, their study demonstrated a strong and independent association between fibrinogen and the presence and severity of hypertension related damage in different target organs [15]. Also our study show that the genders of the patient have no effect on the fibrinogen level both sex has same level of fibrinogen. This finding is agreement with study done by Anoop et al. found that elevated plasma fibrinogen level was positively associated with prevalent hypertension both among men and women [16]. Also study conducted by Folsom et al, and concluded that despite a moderately strong positive association between fibrinogen levels and prevalent hypertension in both sexes, there was only a weak positive association between fibrinogen levels and incident hypertension in men and 
no association in women. Whether an elevated fibrinogen level is a risk factor for, or a consequence of, hypertension remains unclear [17]. Our study is limited by the low number of subjects and other fibrinolytic markers like (D-dimer, PT, PTT and PLTs) must be included in study.

\section{Conclusion}

In conclusion, our study indicates that they significantly increased in fibrinogen level in hypertensive patients compared to control, while the gender showed no effect on the level of fibrinogen.

\section{Acknowledgements}

The authors wish to acknowledge the efforts and assistance given by staff of El-Obied teaching hospital.

\section{References}

[1] Oscar, A. (2000) Carretero and Suzanne Oparil. Essential Hypertension: Part I: Definition and Etiology. Circulation, 101, 329-335.

[2] Psaty, B.M., Lumley, T., Furberg, C.D., Schellenbaum, G., Pahor, M., Alderman, M.H. and Weiss, N.S. (2003) Health Outcomes Associated with Various Antihypertensive Therapies Used as First-Line Agents: A Network Meta-Analysis. JAMA, 289, 2534-2544. http://dx.doi.org/10.1016/s1062-1458(03)00272-1

[3] Chobanian, A.V., Bakris, G.L., Black, H.R., Cushman, W.C., Green, L.A., Izzo, J.L., Jones, D.W., Materson, B.J., Oparil, S., Wright, J.T. and Roccella, E.J. (2003) Seventh Report of the Joint National Committee on Prevention, Detection, Evaluation, and Treatment of High Blood Pressure. Hypertension, 42, 1206-1252.

http://dx.doi.org/10.1161/01.HYP.0000107251.49515.c2

[4] Boschin, G., et al. (2014) Optimization of the Enzymatic Hydrolysis of Lupin (Lupinus) Proteins for Producing ACEInhibitory Peptides. Journal of Agricultural and Food Chemistry, 62, 1846-1851. http://dx.doi.org/10.1021/jf4039056

[5] Gavras, I. and Gavras, H. (2004) Hypertension, Vasoactive Peptides and Coagulation Factors. Journal of Hypertension, 22, 1091-1092. http://dx.doi.org/10.1097/00004872-200406000-00007

[6] Wilhelmsen, L., Svardsudd, K., Koran-Bengtsen, K., Larsson, B., Weilin, L. and Tibblin, G. (1984) Fibrinogen as a Risk Factor for Stroke and Myocardial Infarction. New England Journal of Medicine, 311, 501-505. http://dx.doi.org/10.1056/NEJM198408233110804

[7] Ibrahim, H.M.A. and Abdalla, M.H.A. (2014) D-Dimer Levels in Sudanese Hypertensive Patients. American Journal of Medicine and Medical Sciences, 4, 92-95.

[8] Osman, S.S.A., Ali, A.E. and Muddathir, A.R.M. (2014) Measurements of Plasma Fibrinogen Level, Total Cholesterol and Triglyceride Levels in Hypertensive Sudanese Patients. American Journal of Medicine and Medical Sciences, 4, 161-165.

[9] Ali, N.M.A., Gameel, F.E.M.H., Elsayid, M. and Babker, A.M.A.A.A. (2016) Alterations in D-Dimer, Prothrombin Time and Activated Partial Thromboplastin Time as Thrombogenesis Activity Markers in Patients with Acute Myocardial Infarction. Open Journal of Blood Diseases, 6, 1-5. http://dx.doi.org/10.4236/ojbd.2016.61001

[10] Glueck, C.J., Glueck, H.I., Hamer, T., et al. (1994) Beta Blockers, Lp(a), Hypertension, and Reduced Basal Fibrinolytic Activity. The American Journal of the Medical Sciences, 307, 317-324. http://dx.doi.org/10.1097/00000441-199405000-00001

[11] Letcher, R.L., Chien, S., Pickering, T.G., Sealey, J.E. and Laragh, J.H. (1981) Direct Relationship between Bloodpressure and Blood Viscosity in Normal and Hypertensive Subjects. Role of Fibrinogen and Concentration. American Journal of Medicine, 70, 1195-1202. http://dx.doi.org/10.1016/0002-9343(81)90827-5

[12] Tabak, O., Gelisgen, R., Uzun, H., Kalender, B., Balci, H., Curgunlu, A., et al. (2009) Hypertension and Hemostatic/ Fibrinolytic Balance. Clinical \& Investigative Medicine, 32, E285-E292.

[13] Bennet, N.B. and Ogston, D. (1970) Inhibitions of Fibrinolytic Enzyme System in Renal Disease. Clinical Science, 549, 30-41.

[14] Wardle, E.N., Menon, I.S. and Rastogi, S.P. (1970) Study of Proteins and Fibrinolysis in Patients with Glomerulonephritis. British Medical Journal, 2, 260-263. http://dx.doi.org/10.1136/bmj.2.5704.260

[15] Sechi, L.A., Novello, M., Colussi, G., et al. (2008) Relationship of Plasma Renin with a Prothrombotic State in Hypertension: Relevance for Organ Damage. American Journal of Hypertension, 21, 1347-1353. http://dx.doi.org/10.1038/ajh.2008.293

[16] Shankar, A., et al. (2006) Positive Association between Plasma Fibrinogen Level and Incident Hypertension among 
Men Population-Based Cohort Study. Hypertension, 48, 1043-1049. http://dx.doi.org/10.1161/01.HYP.0000245700.13817.3c

[17] Folsom, A.R., et al. (1998) Plasma Fibrinogen and Incident Hypertension in the Atherosclerosis Risk in Communities (ARIC) Study. Journal of Hypertension, 16, 1579-1583. http://dx.doi.org/10.1097/00004872-199816110-00003 